\title{
Dentro da memória e das águas das identidades: a construção da personagem Rosa Cabral em Dentro de ti ver o mar
}

Within memory and the waters of identity: The construction of the character Rosa Cabral in Dentro de tiver o mar

\author{
Amanda Gomes dos Santos ${ }^{1}$ \\ Vanessa Riambau Pinheiro ${ }^{2}$
}

\begin{abstract}
RESUMO
O propósito desta pesquisa é abordar a personagem Rosa Cabral, que protagoniza o romance português Dentro de ti ver o mar (2013) de Inês Pedrosa. A análise parte da construção dessa personagem feminina por meio das memórias e das identidades que se intercambiam como elementos norteadores da fadista na narrativa.
\end{abstract}

PALAVRAS-CHAVE:InêsPedrosa. Memória. Identidades.

\begin{abstract}
The purpose of this research is to approach the character Rosa Cabral, who stars in the Portuguese novel Dentro de tiver o Mar (2013) by InêsPedrosa. The analysis starts fromtheconstructionofthisfemalecharacterthroughthe memories andidentitiesthat are exchanged as guidingelements in thenarrative.
\end{abstract}

KEYWORDS: Inês Pedrosa. Memory. Identities..

1 A dimensão literária: entre memória e identidade

A Literatura de autoria feminina e as representações de sujeitos femininos são elementos cada vez mais recorrentes e que estabelecem uma simbiose na produção literária. Ao decorrer dos séculos, tal produção se fez

\footnotetext{
${ }^{1}$ Mestra em Letras pelo Programa de Pós-Graduação em Letras da Universidade Federal da Paraíba.(UFPB) Licenciada em Letras com habilitação em Língua Portuguesa pela Universidade Federal da Paraíba (UFPB). E-mail: amanda_gomees@hotmail.com.

${ }^{2}$ Professora Adjunta de Literatura na Universidade Federal da Paraíba (UFPB). Pós- Doutora em Estudos Africanos pela Universidade de Lisboa. E-mail: vanessariambau@gmail.com.
} 
notória ao passo que tais sujeitos foram delineados de formas distintas. A construção de personagens femininas ora buscava personificar uma mulher ideal, ora apresentar ao leitor os devaneios desse ideário feminino. Sabe-se que a Literatura dialoga com as realidades sociais, como aponta Candido (1989) e, por conseguinte, esta se transmuta a partir dos contextos que os escritores estão inseridos, desde a Antiguidade à Contemporaneidade.

Neste tocante, ao se tratar da produção literária contemporânea, ocorre um movimento que provoca ondulações nas produções, sendo ele moldado pela mudança quanto a quem produz essa literatura, como também pelas representações desses sujeitos femininos. Ao constatarmos essa nova conjuntura, nos é apresentada uma outra, correlacionada com a realidade dos sujeitos situados na "modernidade" e/ou pós modernidade. Como trata Hall (2015), a representação desses sujeitos é alicerçada por conflitos das identidades que coexistem e são fragmentadas, consequência de um sujeito deslocado e em constante movimento, fruto das relações fluidas numa sociedade considerada líquida, como aponta Bauman (2005) e são vinculadas à memória, como trata Candau (2016).

Ao passo que a literatura possui uma função coletiva, seja através do conteúdo ou da forma, existe uma premissa que pertence à sociedade humana e que alicerça as relações sociais: a concepção de memória. O texto literário, como arte, possui a proposta de se basear, dentre outras questões, em um caráter estético que retroalimenta a ideia de ser avaliado quanto à qualidade. Sua função social, entretanto, é estabelecida por sua contribuição acerca das temáticas que constituem as relações entre os seres que constituem a comunidade. Discutir sobre memória é trazer à tona a brevidade das relações e como estas são transpostas à memória, posto que a compreensão humana diverge acerca do que aconteceu e de como o acontecimento é relatado. A literatura é crucial para esses horizontes - seja ao tratar de um texto ficcional amparado por fatos históricos que coincidem com o verídico; ou quando tal texto transmuta uma memória não partilhada pelo coletivo.

A memória provoca o exercício de suportar o que já foi vivido por meio da lembrança e alimentar fragmentos que cooperam para encarar um 
presente e/ou futuro através de imagens que repercutem e dialogam com as identidades, pois "de fato, memória e identidade se entrecruzam indissociáveis, se reforçam mutuamente desde o momento de sua emergência até sua inevitável dissolução" (CANDAU, 2016, p. 19). Candau apresenta esse entrelaçamento a partir de duas temáticas: identidade e memória. Tais aspectos são primordiais na perspectiva das produções literárias contemporâneas e, por conseguinte, provocadores de conflitos quando observadas pela ótica dicotômica da tradição e modernidade, posto que ambas são inevitáveis para as relações sociais e consequentemente mutáveis, seja através da arte ou da realidade das situações sociais.

Considerando a perspectiva de que as memórias são sempre imaginadas, o presente estudo intenta realizar uma análise sobre a construção da personagem feminina a partir das suas identidades na obra Dentro de ti ver o mar (2013), da escritora Inês Pedrosa. Tenciona-se compreender a dialética entre identidade e memória na narrativa através da representação da protagonista e nas relações afetivas estabelecidas, visto que estas resultam na fragmentação do sujeito feminino como subterfúgio da sua busca por pertencimento.

2 A construção de Rosa Cabral tecida pela memória e suas identidades

A construção das memórias e a fluidez das identidades se sucedem de forma intercambiante, e essa percepção também é fator constitutivo da protagonista Rosa Cabral, ao situar essa personagem no enredo de uma narrativa que traz à tona fragmentações dos sujeitos. Bauman (2005) traz uma analogia do amor como força propulsora de criação, logo quando a leitura é direcionada para a caracterização da fadista é possível elucidar tal pensamento, pois o amor pode eclodir como uma energia criativa, que por vezes resulta em explosões ou no clímax de destruição.

O tecido que constitui Rosa é intrínseco à essa energia criativa, de modo que a subjetividade do eu lírico da fadista é norteado a partir do que sua subjetividade alimenta, às vezes eclodindo por meio de memórias que 
direcionam seu apogeu ou sua queda ao abismo. E essa eclosão através das memórias das personagens culmina em um questionamento apresentado por Bauman (2005) que se faz provocador, posto que é passível pensar quais as nuances da memória e as concepções de alguns estudiosos acerca dessa categoria:

Será que, aquilo que ostenta um passado mais longo tem maiores probabilidades de ingressar no futuro intacto e incólume do que algo, admitidamente feito e desfeito pelo homem ostensivamente "de ontem ou de hoje "? Não se sabe, mas é tentador pensar que sim. (BAUMAN, 2005 , p. 22)

A dinamicidade entre o passado e o futuro permeia a máxima de que estamos "condenados ao tempo 3 ". Essa constatação resvala na premissa de que as memórias estão condicionadas a essa temporalidade e à possibilidade de acessar tais vivências, como também a mutabilidade de que "juntando os pedaços do que foi numa nova imagem que poderá talvez ajudá-lo a encarar a sua vida presente" (CANDAU, 2016, p. 15).

Através da junção desses pedaços, nutre-se um todo a partir de um jogo dialético, já que "a dialética da memória e da identidade que se conjugam, se nutrem mutuamente, se apoiam uma na outra para produzir uma trajetória de vida, uma história, uma narrativa" (CANDAU, 2016, p. 16). Assim, a construção de Rosa dialoga com essas perspectivas, como é possível perceber nos seguintes excertos:

As nuvens cantavam. Desciam em flocos criando uma cortina de música e prata que isolava Rosa da realidade. A primeira vez acontecera quando Rosa tinha três anos; a empregada doméstica fartara-se da sua irrequietude e fechara-a na despensa às escuras. Rosa chorou durante aquilo que lhe pareceram horas - e era essa a lembrança inaugural da vida: encolhida na despensa, aterrorizada, a chorar e a suplicar que a tirassem dali. (PEDROSA, 2013, p. 49)

${ }^{3}$ Candau faz uso dessa expressão para discutir sobre a condição a qual estamos inseridos, fazendo uso do pensamento de Michel Dumment acerca da voracidade do tempo. 
A "lembrança inaugural" da existência de Rosa se faz a partir de uma memória tangida pelo desconhecido, regida pelo medo e verbalizada pelo choro. A ideia da temporalidade nos é apresentada a partir da metáfora das nuvens como uma "cortina de música", sendo este o princípio para a energia criativa através da arte que personifica uma de suas identidades, traçando assim uma das narrativas que representam a protagonista. A ideia da "lembrança inaugural" pode ser assimilada com a rememoração pessoal discutida por Alexandre (1990) na abertura do livro de Halbwachs (1990) acerca de memória, especificamente ao que se trata sobre memória individual. Alexandre (1990) elucida a junção de elementos que fabricam as lembranças, e sua perspectiva permite compreender a criação da rememoração, anteriormente mencionada, de desamparo vivenciada pela protagonista do romance:

[...] a memória individual existe, mas ela está enraizada dentro dos quadros diversos que a simultaneidade ou a contingência reaproxima momentaneamente. A rememoração pessoal situa-se na encruzilhada das malhas de solidariedade múltiplas dentro das quais estamos engajados. Nada escapa à trama sincrônica da existência social atual, e é da combinação destes diversos elementos que pode emergir esta forma que chamamos de lembrança, porque a traduzimos em uma linguagem. (ALEXANDRE, 1990, p. 14)

A ação de transpor as lembranças através da linguagem é um aspecto que perfila as sensações e emoções, além de ser uma possibilidade de mola propulsora de criação e contato com a arte. Deste modo, pode-se tratar que o ímpeto artístico de Rosa tem um potencial de explosão do que constitui suas memórias e as identidades que são forjadas a partir das interações sociais, perpassadas por emoções que a figuram como intensa, já que a personagem não tinha receio da morte e sim de não se sentir viva: 
Só quem espera a salvação sabe cantar o fado, mas Rosa levava essa esperança a limites perigosos. [...] Na verdade, Rosa não esperava nada a não ser um esforço do desespero. Levara anos a viver cansativamente, por episódios, saltando entre a tristeza e o contentamento. Levara anos a disciplinar-se para cumprir horários e expectativas. Levara anos a aprender a reagir às circunstâncias. Para quê? Sobrava sempre um sentimento amargo de mesquinhez; havia dores que ultrapassavam as suas dores e triunfos que lhe seria impossível alcançar. Só o amor que Gabriel originara nela, um amor escuro, imóvel, feito da matéria da música e das palavras, a empurrara para o interior do seu talento, libertando-a do absurdo da História e da sua contingência. (PEDROSA, 2013, p. 43)

De modo que "só se fixa o que de algum modo foge do olhar" (PEDROSA, 2013, p.52). Ao considerar esse trecho da narrativa, evoca-se a discussão do conceito de memória, posto que ela pode ser apreendida de formas distintas, nas quais são construídas, conscientemente ou inconscientemente - de forma individual ou coletiva —, a relação entre presente e passado, além da sua ligação com a construção da identidade. Como bem pontua Moreira (2016), a memória é um fator primordial para o ato de reconhecer o outro.

Neste aspecto é necessário considerar a construção da memória, neste trabalho, alinhada ao diálogo da categoria identidade, pois:

Compreendemos que a memória está entre uma memória pessoal e uma memória social, o fundamental a destacar consiste no caráter de relação entre ambas. Por isso, podemos falar sobre um percurso do reconhecimento e da alteridade, uma vez que o percurso do reconhecimento de si sempre nos levará ao encontro, ao reconhecimento do outro. (MOREIRA, 2016, p.110)

Neste ponto, salienta-se a relevância da memória na representação do ser, pois ela é uma possibilidade de uma existência que se relaciona com a 
autenticidade das identidades que são construídas e interpostas ao decorrer da interações sociais, já que

sem memória o sujeito se esvazia, vive unicamente o presente, perde suas capacidades conceituais e cognitivas. Sua identidade desaparece. Não produz mais do que um sucedâneo de pensamento, [...] sem a lembrança de sua gênese que é a condição necessária para o conhecimento de si. (CANDAU, 2016, p.60)

De fato, a relação entre memória e identidade é pressuposto para compreender como se edificam ou esfacelam os processos identitários. Social e antropologicamente tais categorias são simbióticas, principalmente nos estudos acerca das relações sociais e da modernidade líquida, para que seja possível evidenciar que as mudanças e provocações dessas categorias são pautadas na transitoriedade, inclusive dos pensamentos críticos que as problematizam.

As consequências dessa imbricação são notórias na protagonista construída por Pedrosa (2013), de modo que pode-se utilizar uma passagem das discussões de Ricouer (2007, p. 107) que caracterizaria a personagem, pois "[a]o se lembrar de algo, alguém se lembra de si”, sendo esse ato de lembrar a raiz das relações da fadista, como também a busca por si pautada na arte, nas relações afetivas, nos discursos, no relacionamento amoroso como também na incessante busca pela figura paterna. A necessidade de lembrar dos momentos partilhados e personificá-los na produção dos fados é um meio de buscar a si, mediante a insistência dessas buscas por si mesma, considerando o imenso desejo de descobrir "Quem sou eu?", questionamento esse que é persistente em todos os capítulos da narrativa, metaforizados ou apresentados de forma denotativa, como na seguinte:

— Quem sou eu? — perguntara Rosa a João, o artista.

E ele respondera:

- És a minha namorada. 
— Quem sou eu? Perguntara a Hélder, o vendedor de remédios.

Respondera:

- És uma tonta.

- Porquê?

- Porque só meninas tontas fazem essas perguntas.

A Gabriel não perguntara nada. (PEDROSA, 2013, p. 47)

De tal modo que a busca pela identidade se torna um fator preponderante para se manter sã em meio aos repertórios conflituosos que se está inserida, já que os aspectos que constituíam a identidade como natural não sustentam mais as âncoras sociais ${ }^{4}$. Logo é imprescindível a vivência do pertencimento que é alimentado através das respostas relacionadas com os laços construídos socialmente, que amortizam a insegurança do questionamento “Quem sou eu?"em uma sociedade líquida, pois:

\begin{abstract}
As afiliações sociais - mais ou menos herdadas - que são tradicionalmente atribuídas aos indivíduos como definição de identidade: raça...gênero, país ou local de nascimento, família e classe social agora estão...se tornando menos importantes, diluídas e alteradas nos países mais avançados do ponto de vista tecnológico e econômico. Ao mesmo tempo, há a ânsia e as tentativas de encontrar ou criar novos grupos com os quais se vivencie o pertencimento e que possam facilitar a construção da identidade. Segue-se a isso um crescente sentimento de insegurança. (DENCIKapud BAUMAN, 2005, p. 30)
\end{abstract}

É importante pontuar uma problematização que Bauman (2005) traz sobre a ânsia pela identidade. Esta, como bem traz o crítico, é uma emoção recheada de ambiguidade, pois surge da busca por uma segurança pautada numa projeção alicerçada numa vivência longe de ser concretizada, já que é uma experiência flutuante e que não necessariamente resultará na

\footnotetext{
${ }^{4}$ Termo utilizado por Bauman para problematizar os "problemas de identidade" no livro Identidade, 2005 .
} 
perspectiva de uma prática que não seja condicionada à ansiedade e à indefinição. Como bem coloca, "as identidade são bênçãos ambíguas" (BAUMAN, 2005, p. 38), já que são determinadas por excessos ou ausências que:

Oscilam entre o sonho e o pesadelo, e não há como dizer quando um se transforma no outro. Na maior parte do tempo, essas duas modalidades líquidomodernas de identidade coabitam, mesmo que localizadas em diferentes níveis de consciência. Num ambiente de vida líquidomoderno, as identidades talvez sejam as encarnações mais comuns, mais aguçadas, mais profundamente sentidas e perturbadoras da ambivalência. (BAUMAN, 2005, p. 38)

Sendo assim, a ambivalência que consiste na matriz das identidades e de sua busca também faz parte de um jogo social, diante de que "a sociedade deseja apenas que você continue no jogo e tenha fichas suficientes para permanecer jogando" (BAUMAN, 2005, p. 58). Na interface desse jogo, os questionamentos se traduzem através de apêndices da modernidade que não necessariamente preenchem o esvaziamento. Na narrativa de Pedrosa, há essa nuance de ambivalência em torno das identidades de Rosa, e elas são demarcadas ao decorrer do enredo, também, no seu encontro com Joaquim, especificamente após o teste de paternidade:

Abriu o envelope e mostrou-a à filha, em silêncio.

Rosa viu os resultados do teste, olhou para o pai e não sentiu nada. Aquele homem não lhe era nada. Ninguém lhe era nada.

- Nada.

- O que é que você quer dizer?

- Nada. Não tenho nada para dizer.

— Eu te entendo.

- Não, você não pode entender nada. Você é apenas outro enganado, como eu. (PEDROSA, 2013, p. 168) 
A ausência de expressar qualquer reação ou emoção diante do reconhecimento do DNA apresenta à protagonista a imersão no limbo, no qual traz a dicotomia que se julgava impossível, pois o intuito de ter o resultado em mãos projetava a garantia de um turbilhão de emoções a partir da relação que deveria se estabelecer com a figura do pai. Entretanto as relações interpessoais também são alimentadas como um espaço de inquietude e que gera uma ânsia, por isso Bauman também afirma que "as relações interpessoais, com tudo o que as acompanha - amor, parcerias, compromissos, direitos e deveres mutuamente reconhecidos -, são simultaneamente objetos de atração e repreensão, desejo e medo; locais de ambiguidade e hesitação, inquietação e ansiedade" (BAUMAN, 2005, p. 68).

Por conseguinte, essa dualidade continua sendo a premissa em prol dessa luz no fim do túnel para a fadista, já que as certezas se esfacelaram no primeiro momento, ao lidar com a confirmação do laço sanguíneo com o brasileiro, que não necessariamente proporciona a quietude ou a grande resposta ao questionamento que norteia a sua ida ao Brasil:

Joaquim respirou fundo e olhou-a frontalmente:

- Tem a certeza que isso importa?

- Acha que eu posso ter a certeza de alguma coisa? Eu nem sei se existo.

- Existe, sim. Ponha o seu nome no Google e vai ver. (PEDROSA, 2013, p.169)

Pautada nesse não saber se existe, a protagonista traz à tona mais uma vez o conflito que roteiriza a modernidade líquida e que persiste na narrativa. Por meio desse questionamento do “Quem sou eu?"há o aspecto das "posições do sujeito5", que são atravessadas por diversos fatores articulados a partir dos relacionamentos que se constituem essenciais para a compreensão de si e dos outros, como também são causa da confusão desses lugares dentro das relações sociais a que são interpelados, pois:

\footnotetext{
${ }_{5}^{5}$ Termo discutido por Hall, em sua obra A identidade cultural na pós-modernidade.
} 
Afinal de contas, a essência da identidade - a resposta à pergunta "Quem sou eu?"e, mais importante ainda, a permanente credibilidade da resposta que lhe possa ser dada, qualquer que seja - não pode ser constituída senão por referência aos vínculos que conectam o eu a outras pessoas e ao pressuposto de que tais vínculos são fidedignos e gozam de estabilidade com o passar do tempo. Precisamos de relacionamentos, e de relacionamentos em que possamos servir para alguma coisa, relacionamentos aos quais possamos referir-nos no intuito de definirmos a nós mesmos. Mas em função de comprometimentos de longo prazo que eles sabidamente inspiram ou inadvertidamente geram, os relacionamentos podem ser, num ambiente líquido moderno, carregados de perigos. Mas de qualquer forma precisamos deles, precisamos muito e não apenas pela preocupação moral com o bem-estar dos outros, mas para o nosso próprio bem, pelo benefício da coesão e da lógica de nosso próprio ser. (BAUMAN, 2005, p. 75)

Com efeito essa "coesão e lógica" do ser estabelece uma profusão de situações diante das relações, já que diante das identidades, a sociedade confronta que se deve ser segmentado pela ideia da escolha em contrapartida a do pertencimento, já que esses aspectos estão relacionados para uma experiência humana bem sucedida e dentro da expectativa da noção de maturidade, em virtude da primeira estar relacionada à escolha, enquanto a segunda envolve a segurança que Bauman (2005) aponta como valores essenciais à existência. À proporção que essas ideias são interpostas, a noção de funcionalidade das identidades aparece, de modo que:

Arrumar a vida em momentos era a regra número um do manual da civilização ocidental, na década zero do terceiro milénio. Absorver a importância da especialização. Somar a inteligência humana ao rigor económico de um canivete suíço: múltiplas funções num único objeto. A concentração em vez da dispersão: agora abro-me e sou um profissional irrepreensível, agora abro-me e sou um pai atento, agora abro-me e sou um amante insaciável, agora abrome e sou um companheiro catita, trato dos impostos e vou às compras. Um dia emperrarei e fechar-me-ei. Não 
digo paz à minha alma porque não há paz neste mundo, nem almas isoladas de momentos e funções. (PEDROSA, 2013, p. 90)

A noção de segmentação apresentada na narrativa propicia um olhar acerca da modernidade líquida, no sentido de que o vivenciar as experiências está relacionado à funcionalidade dos arranjos sociais motivados por expectativas que condicionam as ações a partir dos papeis sociais que são executados a depender da interpelação. Nesse excerto é pulsante a crítica de como a praticidade que se espera desses papeis sociais não permite que haja paz à alma dos homens, diante de que não existem almas que não estejam predispostas a exercer sua funcionalidade em meio ao que se espera como "regra número um" para que a vida esteja adequada à civilização ocidental. Entretanto, essa noção não opera considerando que as identidades são fragmentadas e que não há como serem justapostas em caixas sem que em algum momento se conectem e sejam interpeladas pela experiência de questionar qual a coesão dessas dinâmicas. Além disso, de acordo com Bauman (2005), tais dinâmicas se estabelecem à medida que as identidades são passíveis de mudanças e deslocamentos aparentemente aleatórios por conta do que teórico nomeia "forças de globalização". Tais forças transformam radicalmente o panorama urbano e os locais nos quais os sujeitos tendem a "lançar as âncoras de uma segurança duradoura e confiável. Elas realocam as pessoas e destroem suas identidades sociais" (p.100).

Percebe-se que a compreensão de que a condição da confiabilidade na segurança constitui uma ambivalência, no sentido que as decisões condicionam outras realidades quando estas se fazem presentes. $\mathrm{O}$ intuito de Rosa descobrir a si e pressupor que o encontro com o pai arrefeceria o desejo de pertença por Gabriel traz a forma como as identidades dessa personagem podem ser construídas e vivenciadas, pois "Rosa decidira que quando encontrasse o pai, deixaria de pensar em Gabriel. Estava convencida de que o próprio ato de procurar o homem que a gerara a afastaria da obsessão por aquele outro homem.” (PEDROSA, 2013, p. 141). Neste caso, a protagonista condiciona a descoberta da identidade como filha responsável por sobrepor a 
identidade como mulher que nutre desejo, no caso a ideia de "obsessão" apresentada pela narradora. A confusão que se estabelece no aspecto de que a troca dessas figuras masculinas concederia uma não fragmentação do seu próprio ser denota na narrativa uma intencionalidade de que as certezas a livrariam dos riscos, contudo, como Bauman dialoga sobre a ambivalência pertinente à identidade:

Se você deseja que eu ate os muitos fios que começamos a tecer, mas na maioria dos casos deixamos soltos, eu diria que a ambivalência que a maioria de nós experimenta a maior parte do tempo ao tentarmos responder à questão da nossa identidade é genuína. A confusão que isso causa em nossas mentes também é genuína. Não há receita infalível para resolver os problemas a que essa confusão nos conduz, e não há consertos rápidos nem formas livres de risco para lidar com tudo isso. Também diria que, apesar de tudo, teremos de nos confrontar vezes sem conta com a tarefa da "auto-identificação", a qual tem pouca chance de ser concluída com sucesso e de modo plenamente satisfatório. É provável que fiquemos divididos entre o desejo de uma identidade de nosso gosto e o temor de que, uma vez assumida essa identidade, possamos descobrir, como o fez PeerGynt, que não existe uma "ponte, se você tiver de bater em retirada". (BAUMAN, 2005, p.105)

A divisão entre uma identidade que deseja se projetar em ser genuína e como ela pode se mostrar surpreendente em relação ao modo que as emoções são representadas equivocadamente numa tentativa de "auto-identificação" expõe um paradoxo de sensações que são evocadas pela protagonista, já que existe uma predominância de sua representação, esta ligada à intensidade que anularia a ideia de equilíbrio emocional, que ao decorrer do romance é cobrado à Rosa. Assim, ela vai se construindo, também, a partir das ações intensas, como também das adjetivações que denotam explosão:

— Prefiro sofrer a aborrecer-me. Nunca me aborreço, sabes como é? Às vezes até me canso do meu entusiasmo. Nem que seja um entusiasmo 
mortal: ficar na cama um fim de semana inteiro só a beber e a chorar, como uma boémia qualquer dos anos vinte em Montmartre. A Piaf bebia que se fartava, desgraçava-se sem dó nem piedade. Gosto mais disso do que de uma vida de nada, percebes? (PEDROSA, 2013, p. 97)

Sendo essas explosões também caminhos para a compreensão do desejo que move a fadista a fim de se constituir filha, sem o respingo das dores do amor materno:

- Estou exausta de passamentos. Não queria que aquilo passasse. Queria um pai, qualquer que fosse - criminoso, boçal, indiferente, estúpido. O homem cujo olhar se reconheceria. A sua identidade. A sua pátria, ainda que enlameada. Só no homem que lhe dera origem poderia encontrar essa relação de terra, sem a contaminação de entranhas e vísceras que atrapalhava o amor das mães.

— Pai, pai, porque me abandonaste? (PEDROSA, 2013, p.136)

Diante da exaustão da ausência da figura genitora representada pelo pai, a personagem vai esculpindo várias facetas que podem caracterizar esse homem que pode ser o redentor de boa parte de suas dores que são advindas dessa falta, de modo que ao adjetivar esse "pai" com nuances que não são esperadas de uma figura paterna demonstra a ânsia em reconhecer em alguém uma salvação para o medo que a assola de nunca ter a sua identidade reconhecida, já que a personagem usa a metáfora da "pátria" a fim de relacionar com a pertença afetiva, pois a ideia de se sentir enraizada é diretamente proporcional com a imagem do genitor. Consoante a essa imagem, apenas tal figura poderia despertar e alimentar um amor genuíno, sem as intempéries do amor atribuído à figura materna, primeiro através da figura de Eva e posteriormente à Luiza.

Ainda neste trecho, Rosa faz uma pergunta retórica, "Pai, pai, porque me abandonaste?” (PEDROSA, 2013, p.136). Tal questionamento traz uma intertextualidade com o texto bíblico cristão, no qual Jesus Cristo, prestes a ser crucificado, interpela a figura divina de Deus, seu pai, na hora do 
sofrimento acerca do abandono, por ele, filho daquele que é onipresente, não ser salvo. Considerando a pergunta da protagonista em consonância com a passagem bíblica, a fala da fadista ressalta a dor que se exalta em seu ser, já que esse abandono se constrói em todos os aspectos: Rosa sequer sabe se esse pai reconhece a sua existência. Em todos os planos, o abandono e a busca pela salvação que só aconteceria através dessa figura masculina, assim como na bíblia, denota o amor que a portuguesa alimenta no intento do direito de encontrar o olhar de reconhecimento desse homem que também a originara.

Neste ponto, esse ímpeto de desespero através do questionamento transforma-se numa áurea de tranquilidade. Após as buscas resultarem no encontro com Joaquim, em troca de e-mails com Gabriel, Rosa apresenta a importância para si de encontrar sua "pátria" apesar de "enlameada":

Descobri de onde venho, isso tranquiliza-me.

A maioria dos meus amigos não entende isto. Tantos anos depois de termos acabado com a humilhação dos "filhos ilegítimos" ninguém parece interessado em defender o direito à identidade. É fácil dizer que isso não importa quando sabemos de quem herdámos o quê — porque a herança genética existe, para o melhor e para o pior. (PEDROSA, 2013, p. 174)

[...] O pai biológico pode não ser o pai efetivo - mas cada um de nós tem o direito a saber quem são os seus antepassados. (PEDROSA, 2013, p.

Por meio dessa percepção construída pela personagem tem-se o conceito tratado por Hall (2015) da forma a qual as identidades surgem e como podem ser adquiridas ou destituídas do sujeito, posto que a partir da interpelação a que o sujeito é exposto a sua identidade e o direito dessa de ser representada ganha contornos que passam a considerála como politizada. Neste ponto, é importante perceber também o conflito entre tradição e modernidade no discurso de Rosa, por meio da ideia de que a figura paterna é elemento essencial para o equilíbrio do ser social, já que a "herança genética" 
se mostra fator preponderante a legitimar a identidade do outro, mesmo que tal aspecto evoque situações ou sensações ruins, que sejam nocivas àqueles que buscam percorrer o caminho de desbravar as suas origens. Esse conflito se mostra como mais um sintoma das mudanças estabelecidas pelos modos de vida que norteiam a modernidade, logo as dinâmicas das relações se pautam no interesse da busca da identidade como meio de apaziguar o sofrimento que as ausências não compreendidas nessa dinâmica de liquidez social se apresenta. E Giddens (2002) elucida:

Os modos de vida colocados em ação pela modernidade nos livraram, de uma forma bastante inédita, de todos os tipos de tradicionais de ordem social. Tanto em extensão, quanto em intensidade, as transformações envolvidas na modernidade são mais profundas do que a maioria das mudanças características dos períodos anteriores. No plano da extensão, elas serviram para estabelecer formas de interconexão social que cobrem o globo; em termos de intensidade, elas alteraram algumas das características mais íntimas e pessoais de nossa existência cotidiana. (GIDDENS, 2002, p. 21)

No limiar das mudanças acerca desse direito à identidade na narrativa, coloca-se em discussão a noção do sujeito que se encontra com lacunas ou dividido, considerando que há uma identidade designada como "resolvida" e porquanto não fragmentada em meio às interpelações da celebração móvel. Esta se faz, entretanto, como uma projeção de pessoa delineada por uma união que não se faz compreensível com o ponto da subjetividade. Dialogando com os estudos psicanalíticos, Hall denota que "a identidade é realmente algo formado, ao longo do tempo, através dos processos inconscientes, e não algo inato" (HALL, 2015, p. 24). Dentro desse contexto teórico, sabe-se que não é possível delimitar que haja uma inteireza das identidades. A noção do preenchimento que provoca em Rosa a sensação de tranquilidade perpassa o desejo de pertença afetiva que percorre toda narrativa junto à fadista, pois o romance vai construindo a ondulação das identidades da mesma como uma maré que em um primeiro momento se 
mostra serena, entretanto ao entrar nas águas do enredo, percebe-se que existem pontos de areia que atraem para buracos invisíveis, estabelecendo um ciclo de buscas que se retroalimentam das ausências por meio das palavras, ou que arrebentam através delas por meio das letras de fado, um ponto alto no mar da construção das identidades da portuguesa. Considerando a representação da palavra no romance, é possível relacioná-la com um dos descentramentos desenvolvidos por Hall. Sob o argumento de que as identidades e a liquidez da modernidade também estão descentrando os sujeitos sociais, o teórico traz o terceiro descentramento ${ }^{6}$, acerca da língua e das afirmações que se realizam através das relações, pois:

As palavras são “multimoduladas”. Elas sempre carregam ecos de outros significados que elas colocam em movimento, apesar de nossos melhores esforços para cerrar o significado. Nossas afirmações são baseadas em proposições e premissas das quais nós não temos consciência, mas que são, por assim dizer, conduzidas na corrente sanguínea de nossa língua. (HALL, 2015, p. 26)

E esses "ecos" perpassam as construções identitárias a fim de confrontar as intenções de estabilidade quando se cogita a não-fragmentação do sujeito social. Parte dessa reverberação pode se transformar em energia criativa através da palavra que suplementa os sentidos do que é construído como discurso poético a partir do qual também se nota a ambivalência, já que a busca se faz nas diferenças que surgem pelas relações. A trajetória da palavra condicionada à arte alicerça mais uma busca pela identidade no enredo, além da perspectiva conflituosa da representação do conceito de artista na contemporaneidade e os espaços que são passíveis de ocupação, assim a narradora através da metalinguagem evoca Ovídio e a arte:

\footnotetext{
${ }^{6}$ No terceiro descentramento, Hall discute a partir das descobertas de Saussure acerca do estruturalismo e a ideia da língua como um sistema social, preexistente a nós.
} 
Ter uma arte é viver em função de alguma coisa que excede o acontecer da vida. A arte exige corpo e alma, pensamento e emoção, liberdade e obsessão. O artista, como o amante, tem que ser capaz de sair da sua própria pele para se colocar dentro da pele do outro. Esvaziando-se na entrega, ganha também imunidade à dor - há sempre um lado que contempla, de fora, a obra que dentro de si está gerando. O artista sentese então um surpreendido Deus. O sopro da divindade, ou dessa iluminação súbita que a ela se assemelha, surge no ser humano por intermitências, frágil chama sobre corpos tocados pela vulnerabilidade do conhecimento antecipado da morte. (PEDROSA, 2013, p.88)

Essa profusão de expressões que se coadunam à ideia de ser artista condicionam à existência permeada de paradoxos pautada na busca da súbita inspiração, onde o artista é metaforizado tal qual o amante que no ápice de seus desejos imbrica na pele do outro, para se esvair e entregar-se de tal modo que a fragmentação seja inevitável, pois junto com ela a temporalidade de ser vulnerável emerge de tal forma que o artista se confronta como uma divindade, a qual através da palavra provoca a "morte" antecipada de uma parte de si, sendo essa a função de "ter uma arte".

Assim, a arte que transmuta é um dos eixos das identidades de Rosa Cabral, já que a primeira persona que é apresentada na narrativa acerca da personagem é a de artista, especificamente como fadista. Nesse contexto é pertinente tratar como Andrade (2018), no podcast Curiosidades sobre a representação de mulheres na música em Portugal7, discute as representações das fadistas e os percursos dessas mulheres para "criar um espaço próprio" no sentido de não haver nenhuma figura masculina nesse entremeio, ou seja, que as artistas não fossem projetadas como sombras dos compositores e/ou intérpretes. Em sua discussão a pesquisadora aponta a "imagem de mais valia" que as cantoras buscam construir em prol de situar seus espaços e suas vozes numa Portugal que objetifica aquelas que ocupam os palcos nas noites lisboetas, considerando que apenas em meados de 1925 , 
segundo dados de Andrade, a primeira mulher registrou uma composição na Sociedade Portuguesa de Autores.

É também nesse contexto de construção do próprio espaço quanto fadista que Rosa desponta e se joga nas águas do gênero musical que é tão característico de Portugal.Neste aspecto a narrativa apresenta uma crítica ao que se delineia como arte, pois o fado começa a ser condicionado a "pop lusitana" dentro da modernidade líquida, trazendo consigo a ideia do consumo e dos privilégios que destoam do que anteriormente foi mencionado acerca do ideal de arte relacionado com a produção da protagonista, visto que esta tem o fado como elemento catártico de si contraposto ao ideal de produção artística vinculada à "vontade de poder", pois:

Rosa sabia de cantoras que telefonavam para os promotores de espetáculos a oferecerem os seus préstimos por um preço mais baixo. Diziam que era a lei da concorrência, mas a verdade era mais sombria: vontade de poder. Aniquilar a memória da existência do outro, barbaridade que excedia a lei da sobrevivência animal. Quanto mais se repetia que o fado estava a renascer maior se tornava o assanhamento de cada fadista na defesa do seu território de aplauso. (PEDROSA, 2013, p. 153)

O fado estava na moda enquanto declinação popular e circunscrita da poesia, e garantia uma renda mensal aos poetas que, quando não o eram já, se tornavam especialistas em finanças e se inscreviam na Sociedade Portuguesa de Autores. Nem todos, evidentemente; à parte mantinhase a ilha dourada dos poetasbacteriologicamente-puros, que não queriam confundir-se com escritores de canções e não se misturavam em eventos sociais que não decorressem em bares obscuros apenas frequentados por aspirantes a poetas. [...] Praticamente já só as fadistas mais velhas ou anafadas usavam o vestido preto e os brincos largos, de filigrana portuguesa; o fado cantava-se agora de jeans ou com roupagens de estilistas iguais às das estrelas da pop. Dizia-se que o fado era a pop lusitana. Dizia-se o que fosse preciso para aumentar as vendas e os hábitos de consumo. Os artistas eram ou ambicionavam ser gestores 
culturais e ter convites de primeira plateia para os concertos do Centro Cultural de Belém ou da Fundação Gulbenkian. (PEDROSA, 2013, p. 157)

Por assim saber, desenvolve-se na construção da fadista e sua relação com a arte o aspecto da subjetividade como primórdio do vínculo com a energia criativa. Constatando que, segundo Oliveira (2008), a subjetividade não se resume a comportamentos, também se insere, mas é necessário compreender que está vinculada ao tempo do indivíduo como também ao histórico, já que ela se torna mais enfática ao se tratar dos pensamentos e emoções que se interligam as atitudes do ser social, contudo evidencia um conflito entre o interior com os espaços exteriores. Salienta Oliveira que "enfim não há subjetividade sem sujeito, não há sujeito sem discurso, não há discurso sem destinatário e sem objeto" (OLIVEIRA, 2008, p. 26); desse modo a comoção de Rosa e sua energia criativa e relação com a arte estabelece-se norteada pela subjetividade já que:

\begin{abstract}
Esta noite cantei no bar do meu pai — olha, agora saiu-me assim. Fezse um silêncio total naquele lugar barulhento. E depois um aplauso interminável. Nem sabia como reagir. O que me comove não é o aplauso, o sucesso em si, mas a sensação de ser tão profundamente entendida e amada através do que escrevo e canto, o modo como me abraçam e me agradecem o que encontram nos meus fados, a verdade dessa comunicação. (PEDROSA, 2013, p. 185)
\end{abstract}

A partir do excerto a personagem enfatiza a notoriedade do que o ato de se apresentar e ser acolhida desperta, ou seja, a forma como a subjetividade é construída a partir da relação com o exterior (o público e o abraço de identificação) e os sentimentos que Rosa alimenta, quando o que sobressalta à leitura é a noção de ser "entendida" tal qual ela se expressa pela palavra; já que " a sua voz se erguia, cantando tudo o que não conseguia dizer nem chorar" (PEDROSA, 2013, p. 158), logo a verdade que é estabelecida através dessa comunicação é um indício de que, na arte, a fragmentação de Rosa 
resvala com o potencial do que ela possa vir a ser em meio as suas buscas por responder o questionamento cíclico da narrativa: “Quem sou eu?". Ao passo que os aplausos são a metáfora de que não é a sensação do poder, de ser adorada como musa que a entretém, e sim o que lhe é provocado no campo do sentir, encontrando um modo de ser amada, que no enredo apresenta-se como o primeiro que não culmina em um lugar de submissão, já que estar no palco era sentir o chão, e a sua busca incessante por "terra" ou "pátria" nos corpos dos outros causavam a exaustão.

Sendo assim, a relação de Rosa estabelecida com o fazer artístico se constrói a partir de um espaço que possibilita um novo olhar sobre si mesma, principalmente nesse movimento de migração que acontece com a identificação de territorialidade no Brasil, mesmo que o aspecto da ambivalência ainda persista no discurso da mesma. O jogo de identidades e da memória desponta no enredo mais uma vez, já que "a identidade é a dobra desse dobrar-se sobre si” (RICOUER, 2007, p. 114). A face da energia criativa que alimenta a existência da protagonista é uma dobra que traz a referência à imagem da boneca russa, ou seja, o ato de realizar o movimento de dobrar acerca de si provoca um movimento cíclico, contanto não igual; o modo como a arte a interpela ora sendo levada ao êxtase pelas sensações que o público emana; ora sendo rasgada por criar fados que transfiguravam a imprevisibilidade da paixão. A ação de descobrir a si através das relações é um mote da construção de suas identidades, tal qual a forma como sua memória representa uma faceta que é perceptível em suas composições. Tanto que a máxima de que o fado é um reconhecimento do sofrimento, não assusta a Rosa, pois como traz a narrativa:

Perguntavam-na se as letras dos seus fados resultavam das suas experiências e ela respondia num sorriso de guilhotina, que escrevia à homem, em abstrato, sobre a condição humana.

O pai dissera-lhe:

- O fado é para quem leva pé na bunda e chora por isso. O teu fado é de quem fica feliz de levar pé na bunda. 
$\mathrm{E}$ isso fizera-a rir. Reconhecia a felicidade pelo barulho que fazia quando se quebrava. (PEDROSA, 2013, p. 229)

Posto que essa felicidade se encontra a partir das lembranças que são alimentadas pelas letras de fado, pois a ideia de produzir para um ser abstrato denota a ironia que Rosa faz como parte de uma reação ao fatalismo que carrega consigo. Desse modo, é possível compreender que a consciência que é apresentada das memórias tem um potencial de significado para o entendimento das relações interpessoais, mas também de uma identificação com os outros, considerando que a felicidade e a lembrança são instituídas por sua temporalidade no espaço e que surgem e se esvaem através da subjetivação e da relação com o outro, como traz Husserl:

Tudo aquilo que vale para mim mesmo, vale também, como sei, para todos os outros seres humanos que encontro no mundo que me circunda. Ao ter experiência deles como seres humanos, eu os entendo e aceito como eussujeito, assim como eu mesmo sou um, e como referido ao mundo natural que os circunda. Isso, porém, de tal modo que apreenda o mundo circundante deles e o meu como um só e mesmo mundo, que vem à consciência, embora de maneira diversa, para todos nós. Cada um tem seu lugar, a partir do qual vê as coisas disponíveis, e respectivamente ao qual elas se manifestam diferentemente para cada um deles. Os atuais campos de percepção, de recordação etc., também são diferentes para cada um, sem contar que também aquilo de que estão intersubjetivamente conscientes vem à consciência de modos diferentes, em diferentes modos de apreensão, em diferentes graus de clareza etc. A despeito disso tudo, nós nos entendemos com nossos próximos e estabelecemos em conjunto uma realidade espaço temporal objetiva como mundo que nos circunda, que está para todos aí, e do qual, no entanto, nós mesmos fazemos parte (HUSSERL, [1913] 2006, p. 76-77).

De tal modo que o reconhecimento de si e da relação com a memória levanta a discussão que Ricouer apresenta sobre a ideia de o homem ser 
conceituado como um ser capaz, e dessa dinâmica de como o passado se estabelece sendo responsável ou não por aquilo que cativa na memória:

[...] capaz de se dizer, capaz de fazer, capaz de se responsabilizar, capaz de contar e de se contar, capaz de se lembrar, refazendo laços e dando novos sentidos ao factum, até mesmo ao irreparável e ao injustificável. Por isso, o uso crítico da memória tanto nos impede de ficar amnésicos, como nos liberta da opressão de um passado - congelado, que obsidie a memória com uma fatalidade irreversível. Usar criticamente a memória é, por conseguinte, dizer - não aos — abusos da memória, exigindo trazer para o centro a categoria da relação que outorga unidade narrativa e diferenciada a uma vida, processo que, num mesmo movimento, não esquece o passado, mas recusa ficar dele cativo. Permanecer entre e em relação: é isto que permite o - "trabalho de memória” [...] (ROSA, 2006, p. 2-3)

Nesse processo de "permanecer entre e em relação" que culmina no labor da memória, o enredo apresenta uma metáfora acerca de como esse movimento é construído por Rosa, e consequentemente a temporalidade do desejo é inevitável à personagem, já que estar no modo de espera faz do passado uma ferida aberta:

A noite atiça as memórias, atira-as contra o coração como um lobo esfomeado. O coração é um lobo esfomeado. Pelo menos o de Rosa nunca se fartava de querer. As luzes da cidade têm o efeito contrário; acariciam as memórias, e as carícias trazem o poder do esquecimento, conduzem à névoa da infância. (PEDROSA, 2013, p. 200)

Os sentimentos arrastam-se como malas pesadas cheias de tralha que não sabemos de onde vêm. Rosa sabia que o desejo tem de ser vivido até ao fim. A pausa era-lhe insuportável. Bloqueava-lhe a vida. Viciara-se em conversar com ele, pensar através dele. E em deixar de pensar, deixar de ser, entregando-se. (PEDROSA, 2013, p. 201) 
A metáfora da carícia das memórias que provoca o esquecimento, mas não anula o desejo, elucida a questão do corpo que espelha o desejo, quer dizer, o corpo desejado que lhe é necessário domar, pois "o corpo desejado, o corpo das mulheres é também, no curso da história um corpo dominado, subjugado, muitas vezes roubado em sua própria sexualidade." (PERROT, 2007, p. 76) E essa dinâmica dos corpos também é construção das identidades, assim como espaço da memória; já que o corpo verbaliza o que sobrepuja o externo e eclode os sentimentos. Assim, Rosa edifica sobre si uma identidade como fadista que a torna "radical e sofisticada":

Gabavam-lhe a distinção das pequenas tatuagens: notas de música no pescoço, um pássaro no pulso esquerdo, o sol atrás do joelho direito. Cortara o cabelo em escada irregular, acentuara as sobrancelhas, cantava com vestidos de seda e renda, brancos ou de cores fortes, com frases dos seus fados nas mangas ou nas saias fluidas. Deixara que lhe criassem uma imagem "radical e sofisticada" que lhe assentava bem. (PEDROSA, 2013, p. 229)

Portanto a criação dessa imagem dialoga com a subjetividade da artista que encontra em cada aspecto físico uma dinâmica para estabelecer uma identidade de si que provoque no outro um estranhamento imediato, mas que acolha as singularidades a que ela verbaliza através do corpo. Se a compreensão de cada elemento traçado em seu corpo denota a ideia de liberdade e a relação intrínseca com a arte, assim como o cabelo que destoa do estereótipo das cantoras de fado, e a metalinguagem através de seus vestidos, tais elementos tem uma finalidade por si, pois como discute Hegel:

Não desviando a minha subjetividade da realização do meu fim [...] com isso suprimo, para objetivá-lo, o que nela há de imediato, e assim faço que ela seja a minha subjetividade individual. Ora, a subjetividade que assim me é idêntica é a vontade de outrem [...]. O terreno para a existência da vontade é agora a subjetividade [...], e a vontade alheia é a estranha realidade que apresento à realização do meu fim. A 
realização do meu fim tem pois em si esta identidade da minha vontade e da vontade dos outros, possui uma relação positiva com a vontade alheia (HEGEL, [1820] 1997, p. 101)

De tal forma que a identidade é promovida como uma celebração móvel em que a sua percepção é moldada pela subjetividade, pelas relações interpessoais, as reivindicações da memória e os construtos que perpassam a sua ambivalência. Pois como traz Bauman:

A identidade - sejamos claros sobre isso - é um "conceito altamente contestado" [...] O campo de batalha é o lar natural da identidade. Ela só vem à luz no tumulto da batalha, e dorme e silencia no momento em que desaparecemos ruídos da refrega. [...] A identidade é uma luta simultânea contra a dissolução e a fragmentação; uma intenção de devorar e ao mesmo tempo uma recusa resoluta a ser devorado... (BAUMAN, 2005, p.84)

Portanto, esse estudo apresentou um panorama, que se estabelece a relação entre memória e identidade na construção da personagem Rosa Cabral no romance Dentro de ti ver o mar (2013), por um lado há a ambivalência como aspecto preponderante para a compreensão do surgimento da mesma e dos caminhos que propiciam a possibilidade de processos de identificação que perpassam determinadas relações e/ou a ausência de tais, já que o ato de assumir uma identidade em determinado momento espaço temporal e contexto sociocultural interpelam na narrativa o questionamento que se torna o mote das ações do enredo que perpassam a protagonista, "Quem sou eu"?. Logo, a dinâmica da identidade e memória demonstra as facetas da personagem a partir dessas categorias que contribuem para a análise da condição humana e complexidade das naturezas que são interpostas, como também os meios que a fadista empreende para alcançar a liberdade de vivenciar suas identidades em meio ao caos que é desenhado, ora de forma imposta, ora de forma inconsciente no romance. 
Referências

ALEXANDRE, J. Michel. Introdução. InHALBWACHS, M. A memória coletiva. São Paulo: Centauro, 2006.

ANDRADE, Soraia Simões de. Podcast Curiosidades sobre a representação de mulheres na música em Portugal, 2019. Disponível

em:<https://soundcloud.com/muralsonoropodcast $>$ Acesso em: 10 jan. 2020.

BAUMAN, Zygmunt. Identidade. Rio de Janeiro: Jorge Zahar, 2005.

BERGSON, H. Matéria e memória. São Paulo: Martins Fontes, 1999. Edição original: 1896.

CANDAU, JOEL. Memória e identidade. Tradução: Maria Leticia Ferreira. São Paulo: Contexto, 2016.

CANDIDO, Antonio. A personagem do romance. In:-----; ROSENFELD, Anatol; $A$ personagem de ficção. São Paulo: Perspectiva, 1989.

GIDDENS, Anthony. Modernidade e Identidade. Trad. Plínio Dentzien. Rio de Janeiro: Jorge Zahar Editores, 2002.

HALL, Stuart. A identidade Cultural na pós-modernidade. Trad. Tomaz Tadeu da Silva e Guacira Lopes Louro. 12. ed. Rio de Janeiro: Lamparina, 2015.

HALBWACHS, M. A memória coletiva. São Paulo: Centauro, 2006. Edição original: 1950.

HEGEL, G. W. F. Princípios da filosofia do direito. São Paulo: Martins Fontes, 1997. Edição original: 1820.

HUSSERL, Edmund. Ideias para uma fenomenologia pura e para uma filosofia fenomenológica. Aparecida, SP: Idéias\& Letras, 2006. Edição original: 1913.

MOREIRA, Elton Quadros. Memória, Reconhecimento de si e Alteridade no pensamento de Paul Ricoeur. Disponível em:<http://www2.uesb.br/ppg/ppgmls/wpcontent/uploads/2017/06/Tese-Elton-Moreira-Quadros.pdf> Acesso em: 15 jan. 2020.

OLIVEIRA, Maria Lúcia Wiltshire de. Subjetividades femininas em Teolinda Gersão e Inês Pedrosa. Revista do Núcleo Estudos de Literaturas Portuguesas e Africancas • UFF Capa > v. 1, n. 1,p.26-34,agos,2008. Disponível em:<https://document.onl/documents/subjetividades-femininas-em-teolinda-gersaoe-inesembora-se-possa-falar-de.html> Acesso em: 25 Jan.2020.

PEDROSA, Inês. Dentro de ti ver o mar. Rio de Janeiro: Objetiva/Alfaguara, 2013.

PERROT, Michelle. Minha história das mulheres/Michelle Perrot; [tradução Angela M.S. Côrrea]. - São Paulo: Contexto, 2007.

RICOUER, Paul. A memória, a história e o esquecimento. Trad.: Alain François. São Paulo: Editora da Unicamp, 2007. 
Recebido em janeiro de 2021.

Aprovado em março de 2021. 